\title{
The Contribution of Teachers' Motivation and Characteristics on the Teachers' Performance in Junior High School of Maarif Metro Lampung
}

\author{
Ali Mashari ${ }^{1, a^{*}}$, Ida Umami2 \\ 1Department of Elementary Education Teacher, Teacher Training and Education College, Bandar Lampung, Indonesia \\ 2Department of Guidance and Counseling, IAIN Metro, Indonesia \\ a mashariali62@gmail.com; \\ ${ }^{*}$ Corresponding Author \\ Whatsapp number: [085758847889]
}

How to Cite : Mashari, A., Ummami, I. (2019). The Contribution of Teachers' Motivation and Characteristics on the Teachers' Performance in Junior High School of Maarif Metro Lampung. International Journal for Educational and Vocational Studies, 1 (6), 599-603

\section{ARTICLE HISTORY}

Received: 8 May 2019

Revised: 17 June 2019

Accepted: 11 September 2019

\section{KEYWORDS}

Teachers's Motivation; Teachers's Performance; Maarif Metro Lampung;

\begin{abstract}
The success of the teacher in the teaching and learning process is determined by the teacher's performance as an educator. This performance plays an important role in achieving optimal teaching goals. However, in the reality of the teacher's performance shows less encouraging symptoms that many teaching teachers seem to have the lack mastery in teaching materials, media and methods used in the teaching and learning process. They have a tendency to teach the same materials in the following year while some of teachers arestill not being placed in accordance with their educational background. There is also the lack of encouragement from teachers to excel and compete among others. This research is conducted to reveal the contribution of teachers' motivation and characteristic toward their performance in SMP Ma'arif Metro. The research method used in this research is the quantitative method using Ex Post Facto. The population of this study was all of teacheras many as 38 people and the sampling technique was done by total sampling. The result of the research shows that the teachers' Motivation is $79.4 \%$ of the ideal maximum score and can be categorized as medium category. Teachers' motivation contributes significantly towardTeacher's performance by $41.2 \%$. While the Teachers' Characteristics score is $85.30 \%$ of the ideal maximum score and can be categorized as good category. Teachers' Characteristics contribute significantly towardthe Teachers' Performance by $28.1 \%$, while Teachers' Motivation and Characteristics together contribute significantly toward Teachers' Performance by $32.7 \%$. This study found out that the two predictor variables which are the Motivation and Characteristics of Teachers both individually and jointly made a meaningful contribution toward the Teachers' Performance.
\end{abstract}

This is an open access article under the CC-BY-SA license.

\section{INTRODUCTION}

In this globalization era, the society shows rapid changes. Dealing with these changes, it is necessary to develop the human resources through education as an effort to improve the quality of human welfare. Therefore, Education requires the participation of all parties which one of them is the teacher as the core element.

Teachers as actor of education, who are directly related to students, have an important role in improving the quality of education and determine whether the purpose of education can be achieved or not. The good quality of the curriculum, methods, media, sources, facilities and infrastructure, the success of education are depend on the performance of the teacher. Thus the efforts to improve the quality of education, the ability and the performance of teachers in teaching are really needed to be improved since the teacher's performance in teaching is largely determined by his knowledge and abilities.

The success of the teacher in the teaching and learning process is determined by the teacher's performance as an educator. Performance is the willingness and the ability to do something. If the teacher has a good performance, the results of the teaching-learning process can be implemented well. Therefore, improving the quality of education is closely related to the duties of teachers in the classroom, because all of learning goal can only be achieved effectively and efficiently if it is supported by the improvement of teachers' performance. 
The teacher's performance does not only depend on the teacher motivation, but also the teacher's characteristic. Performance is a function of motivation, capability and the environment. The teacher's ability to teach is determined by the cognitive characteristics of the teacher. These cognitive characteristics include teacher education, training, and work experience, while motivation is indirectly related to teacher's needs.

The teacher is the most dominant and important factor in the teaching and learning process, because for students, the teacher is often used as a role model, even as a figure of self-identification. Therefore the teacher should have good behavior and abilities to develop their students as a whole. To carry out their duties properly in accordance with their profession, the teacher needs to master various things as his competence.

The success of the teacher in the teaching and learning process is determined by his performance. Many factors must be met and considered by the teacher both directly and indirectly which can affect the student learning process. These factors can be described in the following picture:

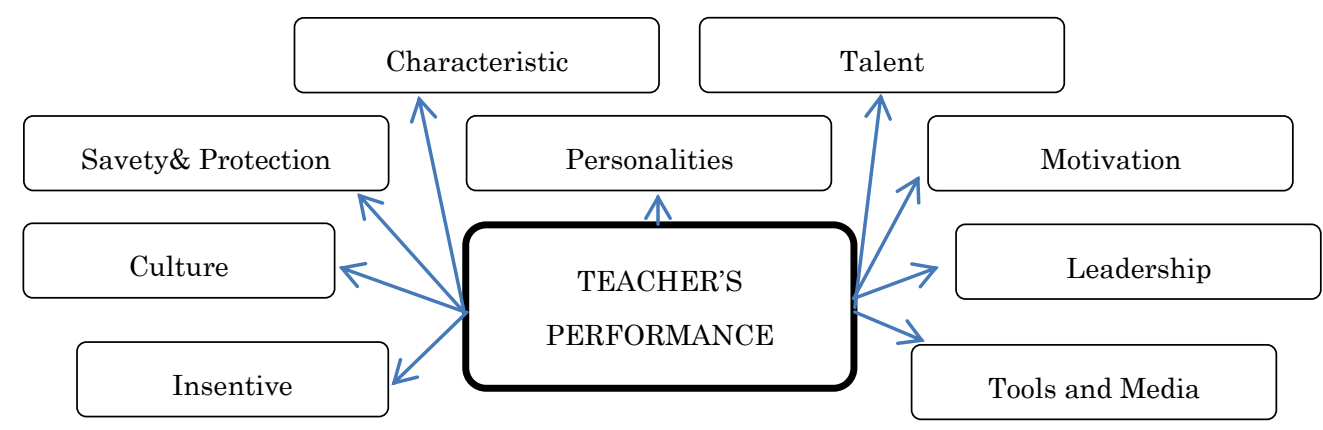

Figure 1: Factors influencing teachers' performance

This study examines various factors that influence teacher's performance consisting of various types of educational inputs that can improve the quality of education, as in the picture above.Based on the picture above, the author can identify the useful problems for research. Identification of problems in this study can be interpreted as research questions.In other words, each research question must be interpreted into an investigative question so that the research questions can be more operational toward the result of the research.

Many definitions given by experts regarding the performance, including Fremont, Kast and Rozenweig (1982) who stated that performance is the process of an individual to achieve the relevant goals. This statement was supported by Benton (1974) that performance is a process of one's actions. So, basically performance is an action in doing something that is desired with certain results.

Gibson, Ivancevich and Donnelly (1992) stated that performance is the same as work achievement for the desired result. In Kamus Besar Bahasa Indonesia (Indonesian dictionary) published by the Ministry of Education (1995), it is stated that performance is: (a) something achieved, (b) performance shown, and (c) ability to work. Timpe (1993) stated that performance is an assessment of the level of work that is clearly done. Work performance is determined by one's interaction with their ability to work, both on the scope of work and the depth of work. This clearly requires an adequate insight into the work job descriptions. Thus performance is the ability of teachers to carry out their duties and responsibilities.

Samana (1994) states that there are ten teacher competencies in Indonesian education system, namely:(a) mastering teaching materials, (b) managing teaching-learning programs, (c) managing classroom activity, (d)mastering the use of media, (e) mastering educational foundations theories, (f) managing teaching and learning interactions, (g) assessing student achievement for the sake of teaching, (h) recognizing the functions and programs of guidance and counseling services, (i) organizing school administration, and (j) understanding and interpreting the results of educational research for teaching needs.

Generally, it can be said that the teaching and learning process is a process that contains a series of actions by teachers and students on the basis of reciprocal relationships that take place in educational situations to achieve certain goals. Wrightman (1977) quoted by Usman (1998) suggests that the role of the teacher is the creation of a series of interrelated behaviors in a particular situation and related to the progress in behavior changes and the development of students character.

Griffin (1986) states that the good performance will be realized if there are: (a) motivation, (b) ability, and (c) work environment. Based on this theory, researchers examinedthe teacher's performance by focusing on motivation and capability. Capability is logically determined by cognitive characteristics which include: teacher education level, teacher upgrading, teacher work experience, and rank group.

Whereas Morris (1986) suggested that cognitive characteristics consisted of: pertaining to, indicating, constituting, distinctive character, quality, disposition, typical." The point is that cognitive characteristics relate to elements, parts of a trait, habit, facts that are inherent and tend to apply to someone. Furthermore, cognitive is 
called "knowledgeable" which means the process or mental ability to gain knowledge.

Teachers are appointed based on government decisions based on certain criteria. This means that the teacher's appointment conditionis to have knowledge of their duties. In addition, the requirements for the appointment of teachers are: (a) the level of education, the teacher appointed is thought to have been educated based on their level of education. Such as: teachers who teach in SMP, of course, at least they have got a S1 diploma, (b) upgrading, this policy means that through upgrading will increase teacher knowledge, and (c) teacher rank group, a teacher increases rank based on credit assessed to determine the credit number for each achievement. This criterion is considered that teachers with high rank groups are estimated to have high knowledge and teachers who have low rank groups have low knowledge. So, this knowledge is being interpreted by the realization of the teacher having knowledge which in this study is called "cognition".Based on this consideration, it can be concluded that the cognitive characteristics of the teacher include: level of education, upgrading, experience, and teacher rank.

Basically, every human activity has a goal to be achieved. To achieve this goal, there is a power that can stimulate someone to behave, namely motivation. Handoko (1997) said that many terms used to describe the motivation such as motives, needs, urge,wish, and the drive. From these the various term of motivation, Handoko defines motivation as a condition in a person who encourages the desire of individuals to carry out certain activities in order to achieve goals. Locke, translated by Ananda (1997) suggests that motives are desires that move someone to act.

According to Steers (1980) English term motivation-motivation comes from the Latin movere means to move. Hasibuan and Mujiono (1996) explain that motivation is the giving of driving force that creates a person's work spirit, so that they will cooperate, work more effectively and be integrated with all their efforts to achieve satisfaction.

According to Wahjosumidjo (1992) motivation is a work motivation that arises in a person to behave in achieving a predetermined goal. In addition, Hersey and Blanchard (1988) suggested that "Motives are the whys of behavior". This implies that only in the presence of a certain impulse that causes why someone behaves or acts something. Furthermore, he argued that "the motivation of people depends on the strength of their motives" . Thus, each person has an urge to do for himself or maybe for others.

From the discussion above, it can be concluded that motivation has an important role for teachers in carrying out their duties. A teacher who has high motivation will have a strong will or sincerity to do his duties, and consequently his productivity in teaching learning will increase. In addition, teacher characteristic can be said as one of the factor that might influence the teacher performance in teaching learning activity. Therefore, this research is intended to reveal the contribution of teacher's motivation and characteristic toward the teacher's performance in Junior High School of Ma'arif Metro.

\section{METHODS}

The research method used in this research is a quantitative method called Ex Post Facto approach. This research was conducted at Islamic Junior Hugh School Maarif Metro Lampung. The populations of this study were all teachers totaling 38 people while sampling technique is done using total sampling. The data analysis has been conducted using product moment correlation and regression.

\section{RESULTS AND DISCUSSIONS}

The first analysis carried out in the research data was the data analysis requirements using the normality test and the homogeneity test. From the results of the analysis, the overall results of the analysis show the probability of significance for each research variable starting from motivation, teacher characteristics, and teacher performance are higher than the significance value $\alpha=$ 0.05 . Thus, it can be said that all of data in this study has already formed a normal and homogeneous distribution. Therefore all test requirements for analysis have been fulfilled, then further hypothesis testing can be carried out.

The first hypothesis in this study was Motivation contribute toward Teacher's Performance at Junior High School of Ma'arif Metro. To prove the hypothesis the test is done by using a formula of Pearson correlation. This analysis uses the help of the SPSS program. The results can be seen in the table as table 1 .

\begin{tabular}{ccccc}
\multicolumn{5}{c}{ Tabel 1. Contribution of Motivation Toward Teacher's Performance } \\
\hline Model & $R$ & $R$ Square & Prob. \\
$r_{y 1}$ & 0,641 & 0,412 &, 000 & \\
\hline
\end{tabular}

a. Predictors: (Constant), X1 (Motivation)

b. Dependent Variable: Y (Teacher's Performance)

As shown in this table, the value of correlation coefficient (ry1) between Motivation variables on Teacher Performance is 0.641 with probability (p) 0,000. Because the probability value $(\mathrm{p})<0.05$ then $\mathrm{Ho}$ is rejected and $\mathrm{H} 1$ is accepted. This means that Motivation contributes significantly toward Teacher's Performance at Junior
High School of Ma'arif Metro

Furthermore, the coefficient value $(\mathrm{r} 2 \mathrm{y} 1)$ is 0.412 , this means that the contribution of Motivation toward Teacher Performance is $0.412 \mathrm{X} 100 \%=41.2 \%$. This is that the amount of Teacher Performance is determined by Motivation as much as $41.2 \%$ while the rest as much as 
$58.8 \%$ is determined by other factors

The second hypothesis tested in this study is the Characteristics of Teachers contribute toward Teacher's Performance at Junior High School of Ma'arif Metro. The hypothesis test that is there a contribution of Teacher Characteristics toward Teacher Performance is carried out using the Pearson correlation formula. The results can be seen in the following table:

Table 2. Contribution of Teacher Characteristics toward Teacher Performance

\begin{tabular}{cccc}
\hline Model & $R$ & $R$ Square & Prob. \\
\hline$r_{\mathrm{y} 2}$ & 0,530 & 0,281 &, 000 \\
\hline
\end{tabular}

a. Predictors: (Constant), X1 (Motivation)

b. Dependent Variable: Y (Teacher's Performance

As shown in the table above the value of correlation coefficient (ry2) between Teacher Characteristics variables on Teacher Performance is 0.530 with probability (p) 0,000. Because the probability value $(p)<$ 0.05 then Ho is rejected and H1 is accepted. This means that the Teacher Characteristics make a significant contribution toward the Teacher's Performance at Junior High School of Ma'arif Metro.

Furthermore the value of determination cooeficient (r2y1) is 0.281 , this means that the contribution of Teacher Characteristics toward Teacher Performance is
$0.281 \times 100 \%=28.1 \%$. This can be concluded that the amount of Teacher Performance is determined by Teacher Characteristics of $28.1 \%$ while the remaining $71.9 \%$ is determined by other factors.

The third hypothesis tested in this study is the Motivation and Characteristics of Teachers contribute together toward the Teacher's Performance of Junior High School of Ma'arif Metro. The hypothesis test is carried out using correlation analysis and multiple regression. The results can be seen in table 3 .

Tabel 3. Contribution of Motivation, Teacher's characteristic toward Teacher's Performance

\begin{tabular}{cccc}
\hline Model & $R$ & $R$ Square & Prob. \\
\hline$R_{\mathrm{y} 1,2}$ & 0,572 & 0,327 &, 000 \\
\hline
\end{tabular}

a. Predictors: (Constant), X1 (Motivation),X2 (Teacher's characteristic)

b. Dependent Variable: Y (Teacher's Performance)

As shown in this table the value of correlation coefficient (ry1,2) between the Motivation variable and Teacher Characteristics on Teacher Performance is 0.572 with a probability (p) 0,000. Because the probability value (p) $<0.05$ then Ho is rejected and H1 is accepted. This means that the Motivation and Characteristics of Teachers contribute significantly toward Teacher's Performance at Junior High School of Ma'arif Metro.

Moreover, the coefficient of termination (r2y12) is 0.327 , this means that the contribution of Motivation and Characteristics of Teachers toward Teacher Performance is $0.327 \mathrm{X} 100 \%=32.7 \%$. therefore, it can be concluded that Teacher Performance is determined by Motivation and Characteristics of Teachers by $32.7 \%$ while the remaining $67.3 \%$ is determined by other factors.

The focus of the problem of this research is the contribution of the Motivation and Characteristics of Teachers toward Teacher Performance at the Junior High School of Ma'arif Metro. The dependent variable is Teacher Performance while the first independent variable is Motivation and the second independent variable is Teacher Characteristics. Based on the result of the data analysis, it can be revealed some of the research discussion which can be described below.

The results of data analysis and hypothesis testing show that the three hypotheses in this study were accepted empirically. Thus it is believed that the Motivation and Characteristics of Teachers contribute significantly toward the Teacher Performance at Junior
High School of Ma'arif Metro both individually and jointly. However, if we compare between those two variables, the Motivation variable contributes higher which is $41.2 \%$ compared to the Teacher Characteristics variable, which only contributes $28.1 \%$.

These data indicate that if we want to improve the Teacher's Performance at Junior High School of Ma'arif Metro, the aspects of teacher motivation in the school and the characteristics of the teacher itself need to be improved, especially about motivation should be given more attention because the contribution of this factor is greater compared to the Characteristics of the Teacher himself.

This is due to the fact that when teachers' motivation in delivering their lessons to students is low, the learning outcomes and also the teaching performance are also low. The research findings also show that the two independent variables above turned out to provide a significant contribution toward the performance of the teacher both individually and jointly. Therefore, the efforts to increase motivation are absolutely necessary, both from ourselves, and from all parties involved. Motivation has an important role for teachers in carrying out their duties. A teacher who has high motivation will have a strong will or sincerity to do his tasks, and consequently his productivity will increase. Conversely a person who has low motivation lacks the willpower to do his job, so his productivity decreases. 
Besides increasing motivation, the teacher must also pay attention to his personal characteristics. Teacher characteristics are shown to influence teacher performance in teaching. Training and any development programs can help teachers to give direction to the characteristics of good teachers, so that the learning process can not be implemented properly. Attempts to improve these two variables (Motivation and Characteristics of Teachers) are expected to improve Teacher Performance.

\section{CONCLUSION}

Based on the results of the data analysis, it can be concluded that Motivation and Characteristics of Teachers contributed significantly toward Teacher's Performance of Junior High School of Ma'arif Metro. These data indicate that if we want to improve the Teacher's Performance at Junior High School of Ma'arif Metro, teacher motivation in the school and the characteristics of the teacher need to be improved, especially about motivation should be given more attention because the its contribution is higher than the Characteristics of the Teacher.

Therefore, it is very important for the Principal to encourage teachers to continue to increase enthusiasm and motivation in teaching. In addition, the teacher must strive to improve learning management for students so that learning can be carried out effectively and efficiently. This can be done by having a good personalities and skills. In addition, Junior High School of Ma'arif Metro's teachers are expected to be able to increase their performance by attending seminars, discussions and training related the improvement of Teacher's Performance and improve their knowledge through continuing to the higher levels of education.

\section{REFERENCES}

Achmadi, Z., A. (1993). Pendidikan akan Gagal Tanpa Guru yang Berkualitas. Jakarta: Republika

Arikunto, S., (1999). Dasar-Dasar Evaluasi Pendidikan Edisi Revisi. Jakarta: Bumi Aksara

Bafadal, I., (1992). Supervisi Pengajaran Teori dan Aplikasi dalam Membina Profesional Guru. Jakarta: BumiAksara

Benton, W., (1974). The New Encyclopedia Entanicos. Volume VII. London: Encyclopedia Britania Inc. Press

Cochran, W., (1977). Sampling Techniques. New Delhi: Eastern Privat Limited

Departemen Pendidikan dan Kebudayaan. 1995. Kamus Besar Bahasa Indonesia. Jakarta: Balai Pustaka

Emory, C. William. 1980. Business Research Methods. Washington: University St. Louis, Richard D. Irwan. Inc

Fremont, K., \& R., (1982). Organisasi dan Manajemen. Jakarta: .Bumi Aksara

Gaellarman, S., (1970). Multivation and Productivity.
New York: Amacom, A Division of American Management Association

Gibson, I., \& Donnelly. D., (1992). Organisasi terjemahan: Djoerban Wahid, Jakarta

Griffin, P., W., (1986). Organizational Behavior. Boston Hougton: Miffin Company

Hajar, I., (1995). Dasar-Dasar Metodologi Penelitian Kuantitatif dalam Pendidikan. Jakarta: Raja Grasindo Persada

Handoko, T.. H.. (1995). Manajemen Personalia dan Sumber Daya Manusia, Yogyakarta: BPFE

Hasan, F., (1998). Langkah Pertama Tingkatkan Mutu Guru dan Sarana. Jakarta: Rosdakarya

Hasibuan, S.P.M., (1996). Manajemen Sumber Daya Manusia Dasar dan Kunci Keberhasilan. Jakarta: CV. Mas Agung

Hersey, P., \& Kenneth H Blanchard. (1988). Management of Organization Behaviour, New Jersey: Prentice Hall

Kerlinger F.N dan Pedhazur E. (1973). Multiple Regression Behavioral Research, New York: Holt. Rinerhart and Wiston

McClelland, david C. 1961. Achievemant Motive. New York: Holt, Richard \& Winston, Inc.

Nugroho, D., (1996). Azas Prilaku Organisasi. Bandung: Mandar Maju

Sahertian, Piet. A. (1994). Profil Pendidikan Profesional. Yogyakarta: Andi Offset

Steers, R., \& M. (1980). Efektivitas Organisasi. Terjemahan Tim Erlangga, Jakarta: .Erlangga

Sudjana, N.. (1995). Metode statistika. Bandung: Tarsito

Suharta, 1995. Administration Behavior on, A Study of Decision Making Process in Administrative Organization, : London: The Free Press

Sunyoto, A., (1995). Manajemen Sumber Daya Manusia, Jakarta: IPWI

Thoha, M., (1990). Prilaku Organisasi. Bandung: Rajawali Press

Tilaar, HAR. (1995). Pembangunan Pendidikan dan Kebudayaan Menjelang Era Tinggal Landas, Jakarta: Depdikbud

Timpe, D., (1993). Kinerja, Jakarta: Media Elekompotindo.

Usman, M.,U., (1998). Menjadi Guru Profesional. Bandung:PT. RemajaRosdakarya

Wahjosumidjo. W., (1992). Kepemimpinan dan Motivasi. Bandung: Rajawali Press. 